\title{
Advancements in Textile Processing
}

\author{
Ashok Athalye* \\ Technical Service, Atul Ltd-Colors Business, India \\ *Corresponding author: Ashok Athalye, Technical Service, Atul Ltd-Colors Business, Valsad, Gujarat, India \\ Submission: 祭 December 11, 2017; Published: 眥 February 19, 2018
}

Abstract

Textile manufacturing is considered to be the mother of industrialization and over the years it has transformed its applications and usage from the basic apparel clothing to the ultra modern technical functions. Viewed as one of the worst polluting industries generating gaseous emission, liquid effluent and solid waste, it is imperative to develop and implement novel methods of processing for enhanced sustainability.

Keywords: Sustainability; Carbon footprint; Renewable polyester; Supercritical $\mathrm{CO}_{2}$; Plasma; Natural dyes

\section{Introduction}

Textile is an integral part of human life, a basic necessity for maintaining modesty, providing protection and improving aesthetics. It is expanding with growing population, per capita consumption and improved standards of living. The impetus for further rapid growth would also depend upon innovative products, application methods and developments in processing machines. At the same time, the textile processing is considered to be one of the most polluting industries and thus, with the growing consumption of textiles the level of pollution is expected to increase proportionately.

With the growing public awareness and concern about issues related to global warming, climate change, emission of greenhouse-gases, carbon footprint, water saving, etc. the textile wet processing has received wider attention and innovative ways are being developed to improve sustainability.

Basically, the textile industry is witnessing a paradigm shift in the concepts, applications and processing technologies. The influencing factors are considered to be the cost pressure, high quality demands, environment regulations, fashion trends and supply chain logistics. This has brought awareness in terms of
a) Conserving - water, energy, electricity, manpower
b) Delivering - superior customer service
c) Improving - supply reliability and reduced inventory
d) Optimizing- processing steps
e) Rationalizing- raw materials, effluent treatment
f) Shortening - production cycles [1]

The amount of water, energy, dyestuff, auxiliaries and time spent on preparation, coloration and finishing of textiles and on the containment of effluent liquor is adding to the woes of the processors and making wet processing the weakest link among the entire textile supply chain. This has influenced development of new textile fibers, dyestuff, chemicals, machines and processing techniques.

Given below are some recent developments and emerging trends, categorized based on the various components of textiles manufacturing. These advancements are aimed to achieve 3R's reduce, recycle and reuse.

\section{Substrate}

Fibers derived from natural and renewable sources have smaller carbon footprint and are easily decomposed by micro-organisms. On the other hand, Synthetic fibers are derived from depleting fossil fuels and do not decompose. Therefore, the development of new fiber like corn based Poly Lactic Acid (natural polyester) can help reduce environment impact of one of the most widely consumed textile fiber 'synthetic Polyester' [2]. Likewise, usage of innovative fibers derived from natural and renewable sources like bamboo, soya bean (vegetable protein), etc. would also help improve sustainability. Developments in morphologically derived fibers exhibiting structural coloration based on the interference properties of light could eliminate need of separate coloration process [3].

\section{Machine}

Development and use of ultra-low liquor ratio machines is envisaged to reduce consumption of water during preparation, coloration and post dyeing wash off. Simultaneously, it helps reduce energy required for water heating during processing steps and the ultimate load on the effluent treatment. The recent development in machinery based on concepts of pulsating dosage and wave technology would help drastic reduction in consumption of water [4]. Further advancements in terms of pre-heating of process water 
by Solar panels to reduce consumption of other non-renewable energy sources (fossil fuels, wood, husk, etc.), adequate insulation of dyeing, drying and stenter machines and appropriate heat recovery systems would avoid undesired energy loss.

\section{Water}

Believed to be abundantly available in nature but in reality less than $3 \%$ of total water on planet earth is considered to be suitable for human consumption. Out of that, a large quantity is utilized by textile industry. It is estimated that for $1 \mathrm{~kg}$ of cotton processing consumes close to $100 \mathrm{~L}$ of water and further that much amount of wastewater needs treatment to make it pollution free effluent. Thus, based on a vast research, scientists and technologists have developed some innovative ways to reduce or eliminate usage of water to the maximum possible extent. It is proposed that certain gases, when converted to super critical fluid under certain specific conditions of pressure and temperature, can replace water. Carbon dioxide $\left(\mathrm{CO}_{2}\right)$ is abundantly available in the atmosphere and has same properties everywhere, is found to be best suited for this purpose. Some dyestuff and machinery manufacturers have developed this technique of using supercritical fluidized $\mathrm{CO}_{2}$ for disperse dyeing of polyester. Other methods involve use of Plasma (fourth state of matter), use of LASER (light amplification by stimulated emission of radiation) beam technology and the air-dye technique for such applications [5].

\section{Energy}

Considering the adverse effects of global warming, oceanic temperature rising, glaciers melting, etc. a pressing need is felt in the textile industry to devise methods and ways whereby the large energy consuming processing steps and methods can be reduced or abolished. This may be achieved by the various methods such as the use of abundantly available, renewable and clean source of energy from the sunlight. This is possible by enhancing usage of radiofrequency drying, microwave simulated batching [6], infrared heating, ultrasonic dyeing [7] electro chemical dye reduction [8], etc. Such methods conserve energy by ascertaining textile processing and coloration at lower temperatures and within less time.

\section{Colorants}

Use of dyes and pigments for enhancing aesthetic appeal and attractiveness of textile material is well known. However, the manufacturing of synthetic colorants involves generation of a large amount of gaseous emission, liquid effluent and solid waste. The reputed color manufacturers have initiated and developed ways to curb and reduce such pollution. However, during the textile application, considerable amount of unfixed / unreacted/excess quantity of the colorants goes into effluent and causes resultant effluent treatment hazard and cost. The dyestuff manufacturers have developed and further working on high purity high fixative type dyes to overcome this issue. Moreover, researchers are exploring use of natural dye extracts from fungus and bacteria [9] as well as developments of ecological mordants for suitable application [10]. Developments in the area of salt and alkali free reactive dyeing, low temperature polyester dyeing, low temperature pigment curing, ink jet printing, catalyzed dye manufacturing, electrochemical dyeing of vat and sulfur dyes, efficient solvent recovery, etc. are in the advanced stages of progress [11,12].

\section{Chemicals}

A large number of basic and auxiliary chemicals are used during various stages of textile processing. Considering various eco-toxicological concerns it is desired that not only reduction in consumption but also the usage of many of such chemicals wherever possible be avoided. This has triggered development of innovative enzyme based biodegradable green chemicals, low no foam surfactants, non-fluoropolymer based water repellents, halogen free flame retardants, microencapsulated coatings $[13,14]$.

\section{Processing}

Depending on the type of fiber, machinery and method of application the textile material passes through a number of processing steps. For improving productivity and reducing time without affecting quality, measures like combining two or more steps together or omitting an intermittent step, are being taken. Some methods combine scour and bleach, peroxide neutralizing and bio softening, one bath one step dyeing of polyester-cotton (P/C) blends, combined dyeing and finishing, etc. [15].

Further, stricter control over processing parameters help improve Right First Time (RFT) and Right Every Time (RET) performance and thereby help in achieving reduction, recovery and reuse of dyes and chemicals. The ultimate objective is to meet the stringent end user requirements in terms of desired performance and fastness parameters.

\section{Statutory}

Various regulatory norms are set by local authorities, Government organizations, international brands and consumer associations in terms of gaseous emission, liquid effluent and solid waste control for zero discharge of hazardous Chemicals (ZDHC). Monitoring and controlling biodegradability, product life cycle assessment, restricted substances, etc.

\section{Summary}

Innovative products and processes are being developed by researches and organizations across the globe for minimizing the textile processing steps and offering alternative sustainable technologies for ultimate reduction, reuse and recycle. The sustainability aspects, like water, energy and ecology savings are key concerns of the textile industry and novel technologies, in turn, are expected to pave the path to achieve such savings.

\section{References}

1. Rao J V, Parmar MS (2010) Emerging trends in Textile Materials for Personnel Protection.

2. Farrington DW, Lunt J, Davis S, Blackburn RS (2005) Biodegradable, sustainable fibers. Elsevier.

3. Teijin Fibers ltd (2015) Morphotex structural colored fibers. Ask Nature.

4. Lorris Bellini (2016) Technology for environment. 
5. Rupp J (2008) Ecology and economy in textile finishing. Text World.

6. Katovic D Microwaves solution for improving woven fabric. In: Polona Dobnik Dubrovski (Ed.), Woven Fabric Engineering.

7. Sanislav A, Fogorasi MS, Stanescu MD, Muntean SG, Dochia M (2015) Ultrasound effect on dyeing wool fibers with two anthraquinone dyes. Fiber Polymer 16(1): 62-66.

8. Sala M, Guti'errez-Bouz'an MC (2012) Electrochemical techniques in textile processes and wastewater treatment. Inter National Journal of Photoenergy 2012: 1-12.

9. Poorniammal R, Parthiban M, Gunasekaran S, Murugesan R, Thilagavathi G (2013) Indian Journal of Fibre Textile Research 38: 276-279.
10. Lodrick MW, Kidist T, Senelisile M (2015) International Journal of Textile Science 4(2): 36-41.

11. Sharma A (2015) Upcoming Trends in Printing Technology. Tech \& Trends.

12. Das D, Chatterjee KN, Arora S (2012) Journal of Industrial Textiles.

13. Athalye A (2014) Bleach Clean-up.

14. Nelson G (2002) Application of microencapsulation in textiles. Int J Pharm 242(1-2): 55-62.

15. Athalye A (2017) International Journal of Textile Engineering and Processing. pp 4-8.
For possible submissions click Here
Submit Article
Your subsequent submission with Crimson Publishers will attain the below benefits

- High-level peer review and editorial services

- Freely accessible online immediately upon publication

- Authors retain the copyright to their work

- Licensing it under a Creative Commons license

- Visibility through different online platforms

- Global attainment for your research

- Article availability in different formats (Pdf, E-pub, Full Text)

- Endless customer service

- Reasonable Membership services

- Reprints availability upon request

- One step article tracking system 